\title{
Konstruksi Bahan Ajar Kimia SMA Konteks Termokimia Berbasis Environment Discovery Learning untuk Meningkatkan Pemahaman Konsep Siswa
}

\section{Construction of Chemical Teaching context Thermochemistry Base on Environment Disccovvery Learning to Increase Student Concept Understanding}

\author{
Florida Doloksaribu, Werima Gombo \& Irwandi Yogo Suaka \\ Universitas Cenderawasih, Jayapura, Papua, Indonesia \\ floridadolok@gmail.com
}

Naskah diterima tanggal 17/06/2020, direvisi akhir tanggal 06/08/2020, disetujui tanggal 30/08/2020

\begin{abstract}
Abstrak
Penelitian ini bertujuan untuk merekonstruksi modul kimia konteks Termokimia berbasis Environtment Discovery Learning (EDL). Hasil observasi menunjukkan, peserta didik kelas XI IPA SMAN 3 Jayapura memiliki nilai kimia yang cukup baik, namun masih perlu ditingkatkan lagi. Hasil penelitian ini untuk mengetahui kelayakan bahan ajar kimia konteks termokimia berbasis $(E D L)$ yang direkonstruksi. Teknik yang digunakan dalam mengumpulkan data adalah tahapan model education reconstruction (MER) yaitu kelayakan bahan ajar, uji skala terbatas, serta tanggapan guru dan peserta didik. Angket validasi ahli terdiri dari validasi konten materi, media, dan bahasa. Nilai validasi expert judgment konten materi sebesar 69.49\%, (layak digunakan), media sebesar $63.89 \%$ (layak digunakan), bahasa sebesar $86.36 \%$, (sangat layak digunakan), dan nilai rata-rata expert judgement dari ketiga validator sebesar 73,24 \% (layak). Nilai tanggapan guru terhadap modul sebesar sangat positif sebesar $62.4 \%$ dan positif sebesar 37.6\%., tanggapan siswa sangat positif $62.4 \%$, positif sebesar $37.6 \%$. Tes yang dilakukan kepada peserta didik menggunakan 30 butir soal pilihan ganda pre test dan post test dengan hasil $n$-Gain sebesar 0,5 termasuk pada kategori sedang artinya terjadi peningkatan pemahaman konsep peserta didik.
\end{abstract}

Kata kunci: Environtment Discovery Learning, Modul, Rekonstruksi, Termokimia.

\begin{abstract}
This study aims to reconstruct the thermochemical context chemistry module based on environment discovery learning (EDL). The results of the observation showed that students of class XI IPA of SMAN 3 Jayapura had quite good chemical values, but they still needed to be improved. The results of this study are to determine the feasibility of the thermochemistry context based on EDL and how to enhance students' understanding concepts. The techniques used in collecting data are model education reconstruction (MER) step, questionnaire, tests, and documentation. The questionnaire used in this study was an expert validation, teacher responses and student responses. Expert judgment value validation value of material content is $69.49 \%$, media is $63.89 \%$ (feasible), and language is $86.36 \%$, (very feasible), and the average value of expert judgment from the third validator is $73.24 \%$ (feasible). The responses of teachers to modul were very positive at $62.4 \%$ and positive at $37.6 \%$, respon students were very positive $62.4 \%$ and positive $37.6 \%$. Tests conducted to students using 30 multiple choice items pre-test and post-test with n-Gain results of 0.5 included in the medium category means an increase in understanding of students' concepts.
\end{abstract}

Keywords: Environment Discovery Learning, Modules, Reconstruction, Thermochemistry. 


\section{PENDAHULUAN}

Peningkatan mutu pendidikan adalah usaha yang terencana untuk mewujudkan sistem belajar dan pembelajaran. Hal ini diharafkan agar peserta didik dapat secara aktif mengembangkan potensi diri untuk memiliki kekuatan spiritual keagamaan, pengendalian diri, kepribadian, akhlak mulia serta keterampilan yang diperlukan melalui proses pembelajaran baik secara formal, informal dan non formal. Hal ini telah tertera pada tujuan pendidikan nasional, yaitu mengembangkan potensi peserta didik agar menjadi manusia yang cerdas serta bertanggung jawab (UU Nomor 20 Tahun 2003). Kualitas Pendidikan di Indonesia belum seluruhnya maksimal, berdasarkan survei United Nations Educatinal Scientific and Cultural Organization (UNESCO) dalam Global Education Monitoring (GEM) Report 2016.

Perbedaan kualitas pendidikan di Indonesia dipengaruhi oleh beberapa faktor, salah satunya faktor kesenjangan pendidikan dalam bidang pemerataan pembangunan, hal ini terlihat pada perbedaan tingkat kelulusan berdasarkan hasil ujian nasional peserta didik di berbagai daerah di Indonesia terlebih khususnya pada bidang kimia. Secara umum terjadi penurunan rerata nilai $U N$, terutama untuk mata pelajaran matematika, fisika dan kimia yang disebabkan dua faktor yakni pertama beberapa soal dengan standar kemampuan High learning Order Thinking Skill (HOTS) yang tidak merata, yang kedua karena perubahan model ujian nasional berbasis kertas dan pensil (UNKP) ke ujian nasional berbasis komputer (UNBK).

Berdasarkan situasi tersebut sekolah membutuhkan banyak guru yang berkualitas untuk meningkatkan mutu pembelajaran yang mendukung kualitas pendidikan di Papua. Perbedaan fasilitas dan kurang tersedianya sarana pembelajaran yang memadai seperti bahan ajar memengaruhi mutu pendidikan sehingga diperlukan guru yang berkualitas. Guru yang berkualitas harus melaksanakan proses pembelajaran yang menarik dan menyenangkan sehingga proses pembelajaran dapat berlangsung dengan baik. Inovasi guru dalam meningkatan mutu pembelajaran dapat melalui pengembangan metode, model, dan pendekatan pembelajaran serta bahan ajar. Bahan ajar sebagai salah satu sumber dan media pembelajaran yang dapat meningkatkan keaktifan dan pemahaman peserta didik terhadap materi pelajaran adalah modul atau bahan ajar lainnya. Modul adalah salah satu bahan ajar yang disajikan secara sistematis dan lengkap sehingga peserta didik dapat belajar sendiri maupun dengan guru. Peserta didik dapat belajar secara mandiri menggunakan modul baik di sekolah maupun di rumah sesuai kemampuan belajarnya (Yerimadesi et al., 2017; Yerimadesi et al., 2017). Bahan ajar berupa modul larutan penyangga berbasis discovery learning sangat praktis digunakan pada pembelajaran kimia SMA/MA.

Penggunaan modul sebaiknya dikembangkan sesuai dengan kebutuhan peserta didik tanpa menghilangkan sistematika penyusunan modul berdasarkan kurikulum yang berlaku. Salah satu cara mengembangkan bahan ajar berupa modul dapat menggunakan Model Education Reconstruction (MER) (Doloksaribu et al., 2014; Duit et al., 2012). Rekonstruksi bahan ajar disajikan dengan kerangka teori yang mengajarkan fakta sains yang terdiri dari komponen analisis struktur konten, penelitian mengajar, serta pengembangan dan evaluasi pelajaran. Penyajian konten secara ilmiah sebaiknya tidak langsung dari buku teks karena hal ini tidak accessible, melainkan perlu dilakukan "Penyerderhanaan" teks (Doloksaribu et al., 2014). Demikian halnya apa yang dikembangkan oleh Rostikawati \& Permanasari (2016), proses model rekonstruksi pendidikan memiliki pengaruh yang besar dan dapat meningkatkan literasi sains peserta didik. Pengaruh yang besar terhadap literasi sains peserta didik disebabkan proses rekonstruksi bahan ajar yang dilakukan dengan mempertimbangkan tujuan pendidikan dan aspek kognitif serta afektif, sehingga materi pelajaran lebih mudah dipahami oleh siswa. Salah satu kebutuhan siswa adalah melalui pendekatan discovery learning (Arends, 2008; Budiningsih, 2005; Istikomah, 2013; Pratiwi et al., 2014).

Penggunaan modul dapat memberikan motivasi intrinsik peserta didik dalam belajar kimia dan peserta didik yang belajar menggunakanmodulmemilikimotivasi intrinsik lebih tinggi dibandingkan dengan belajar tanpa modul. Pembelajaran dengan modul juga bermanfaat bagi guru, karena mendukung peran 
guru sebagai fasilitator sehingga pembelajaran dapat berjalan lebih efektif. Hasil analisis terhadap kompetensi dasar dan pengembangan indikator materi kesetimbangan kimia, rekonstruksi modul kesetimbangan kimia berbasis kebutuhan dapat memudahkan peserta didik memahami konsep-konsep dasar mmateri sehingga peserta didik dapat menemukan fakta, konsep dan prinsip yang terdapat disekitarnya. Latihan soal diperlukan untuk materi ini karena terdapat perhitungan-perhitungan (Yerimadesi et al., 2017).

Selain itu, tema Environment Discovery Learning telah di pakai dalam beberapa penelitian dengan subjek yang berbeda yaitu penelitian (Ariyana, 2011; Erlidawati \& Habibati, 2020; Indriyanti \& Prasetyo, 2018; Nur et al., 2020; Prakasiwi \& Ismanto, 2018; Resty et al., 2019; Rubini et al., 2017). Fenomena-fenomena permasalahan diatas juga terjadi pada pembelajaran kimia di beberapa SMA di Jayapura. Pembelajaran kimia di sekolah belum efektif, disebabkan peserta didik merasa sulit memahami materi yang diterima. Hal ini ditunjukkan dari hasil ulangan kimia peserta didik yang belum maksimal. Selain itu, konsep kimia yang disajikan dalam buku ajar yang digunakan masih menyulitkan peserta didik agar mampu belajar secara mandiri, mengakibatkan rendahnya pemahaman peserta didik terhadap konsep-konsep dasar kimia. Berdasarkan latar belakang diatas maka telah dilakukan penelitian dengan merekonstuksi modul pembelajaran kimia yang berjudul Rekonstruksi Modul Kimia SMA Konteks Terokimia.

\section{METODE PENELITIAN}

Penelitian ini bertujuan untuk merekonstruksi modul kimia konteks Termokimia berbasis Environtment Discovery Learning (EDL). Jenis penelitian yang dipakai dalam penelitian ini adalah deskriptif kuantitatif non eksperimen dengan medeskripsikan datadata yang diperoleh dari hasil rekonstruksi, studi kepustakaan, hasil angket dan tes. Sedangkan model rekonstruksi berdasarkana model education reconstruction (MER) oleh Duit (2007), seperti pada Gambar 1 yang dimodifikasi oleh Doloksaribu (Doloksaribu et al., 2014).

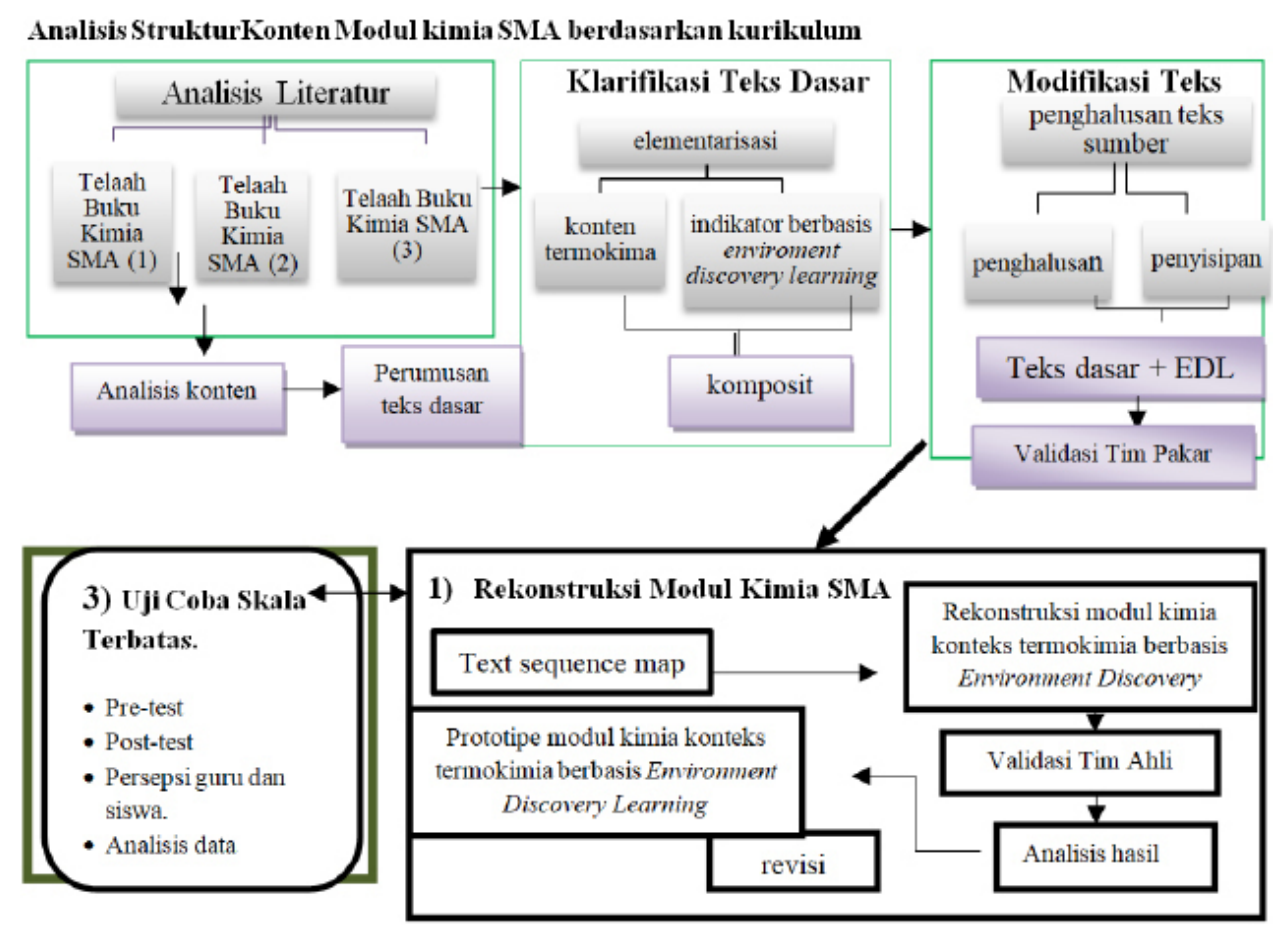

Gambar 1. Skema Alur Rekonstruksi Bahan Ajar Berupa Modul Kimia

Partisipan dalam uji coba skala terbatas pada penelitian ini adalah siswa SMAN 5 Buper Waena Jayapura, kelas XI IPA sebanyak 16 orang tahun ajaran 2018/2019. Sedang kelayakan modul divalidasi oleh 3 orang validator dengan metode expert 
judgement. Pengumpulan data berdasarkan hasil nilai pretes dan postes konsep materi termokimia, dan dianalisis berdasarkan statistik sederhana dan N-gain. Selain itu disebarkan instrumen angket skala sikap, untuk mengetahui tanggapan siswa terhadap modul yang diberikan.
III. HASIL DAN PEMBAHASAN

3.1. Hasil

Rekonstruksi modul termokimia berbasis Environtment Discovery Learning menggunakan adaptasi MER. Referensi sumber kurikulum 2013 terdiri dari 3 buku kimia SMA terakreditasi ditunjukkan pada Tabel 1 .

Tabel 1. Referensi Buku Teks

\begin{tabular}{|c|c|c|}
\hline $\begin{array}{l}\text { Kimia SMA/MA Kelas XI } \\
\text { Penerbit Erlangga } \\
\text { (Oleh: Unggul Sudarmo) } \\
\text { Teks Asli } 1\end{array}$ & $\begin{array}{c}\text { Kimia SMA/MA Kelas XI } \\
\text { Penerbit Yrama Widya } \\
\text { (Oleh: Dini Kurniawati) } \\
\text { Teks Asli } 2\end{array}$ & $\begin{array}{c}\text { Kimia SMA/MA Kelas XI } \\
\text { (Oleh:Tim Masmedia Buana } \\
\text { Pustaka) } \\
\text { Teks Asli } 3\end{array}$ \\
\hline $\begin{array}{l}\text { Secara tradisional, penduduk } \\
\text { Indonesia menggunakan tungku } \\
\text { dari kayu untuk memasak. Pada } \\
\text { perkembangannya, digunakan minyak } \\
\text { tanah sebagai bahan bakar untuk } \\
\text { memasak (menggunakan kompor } \\
\text { minyak). Sekarang, kompor minyak } \\
\text { sudah jarang digunakan karena } \\
\text { pemerintah telah melakukan program } \\
\text { konversi minyak tanah menjadi LPG } \\
\text { (elpiji). Hal ini karena LPG lebih } \\
\text { efisien dan lebih murah. Benarkah } \\
\text { pemakaian elpiji lebih murah dan } \\
\text { lebih efisien dari pada minyak tanah? } \\
\text { Jawaban terhadap permasalahan } \\
\text { tersebut dapat dipahami apabila } \\
\text { telah memahami konsep tentang } \\
\text { termokimia. } \\
\text { Termokimia adalah bagian dari ilmu } \\
\text { kimia yang mempelajari ....dst. }\end{array}$ & $\begin{array}{l}\text { A. Pengantar Mengenai } \\
\text { Perpindahan Energi dan Panas } \\
\text { Reaks } \\
\text { Pada malam hari, lantai terasa } \\
\text { lebih dingin daripada karpetyang } \\
\text { ada dalam ruang yang sama. Hal } \\
\text { ini menunjukkan bahwa kedua } \\
\text { objek ini memiliki perbedaan } \\
\text { suhu. Karpet merupakan salah } \\
\text { satu contoh bahan penghambat } \\
\text { panas (thermal insulator) yang } \\
\text { cenderung mencegah suatu objek } \\
\text { menjadi lebih panas atau lebih } \\
\text { dingin. Disisi lain, secangkir } \\
\text { kopi yang berada pada suhu } \\
\text { kamar mengalami penurunan } \\
\text { suhu secara teratur, Fakta yang } \\
\text { lain, jika kita memasukkan } \\
\text { wadah es dari bahan llogam } \\
\text { dan plastik kedalam pendingin, } \\
\text { wadah dari bahan logam teras } \\
\text { lebih dingin daripada ...... dst. }\end{array}$ & $\begin{array}{l}\text { A. Energi dan Entalpi Zat } \\
\text { Berdasarkan peristiwa tersebut di } \\
\text { atas, manakah yang jika kita pegang } \\
\text { atau berada disekitarnya akan terasa } \\
\text { panas? Mana pula yang terasa dingin? } \\
\text { Mengapa ada reaksi yang terasa } \\
\text { panas dan ada yang terasa dingin? } \\
\text { Peristiwa pembuatan tempe oleh } \\
\text { mikroorganisme dan pembakarankayu } \\
\text { merupakan contoh reaksi eksoterm. } \\
\text { Sedangkan peristiwa pembekuan } \\
\text { es merupakan reaksi endoterm. } \\
\text { Apakah yang dimaksud dengan reaksi } \\
\text { eksoterm dan endoterm? Mari kita } \\
\text { pelajari dalam uaraian berikut. } \\
\text { 1. Hukum Kekekalan Energi } \\
\text { Hukum kekekalan energi berbunyi } \\
\text { "Energi tidak dapat diciptakan atau } \\
\text { dimusnakan. Energi hanya dapat } \\
\text { diubah bentuknya dari satu jenis } \\
\text { energi ke jenis energi ...dst. }\end{array}$ \\
\hline
\end{tabular}

Selanjutnya materi pada tabel 1 dan seperti pada Tabel 2. digabungkan untuk mendapatkan teks dasar

Tabel 2. Klarifikasi Teks dan Penggabungan

\begin{tabular}{|c|c|c|c|}
\hline Teks Asli 1 & Teks Asli 2 & Teks Asli 3 & \\
\hline $\begin{array}{l}\text { Secara tradisional, } \\
\text { penduduk Indonesia } \\
\text { menggunakan tungku dari } \\
\text { kayu untuk memasak. } \\
\text { Pada perkembangannya, } \\
\text { digunakan minyak tanah } \\
\text { sebagai bahan bakar untuk } \\
\text { memasak (menggunakan } \\
\text { kompor minyak). Sekarang, } \\
\text { kompor minyak sudah jarang } \\
\text { digunakan karena pemerintah } \\
\text { telah melakukan program } \\
\text { konversi minyak tanah } \\
\text { menjadi LPG (elpiji). Hal } \\
\text { ini karena LPG lebih efisien } \\
\text { dan lebih murah. Benarkah } \\
\text { pemakaian elpiji lebih murah } \\
\text { dan lebih efisien dari pada } \\
\text { minyak tanah?....dst }\end{array}$ & $\begin{array}{l}\text { A. Pengantar Mengenai } \\
\text { Perpindahan Energi dan } \\
\text { Panas Reaks } \\
\text { Pada malam hari, lantai } \\
\text { terasa lebih dingin dari } \\
\text { pada karpet yang ada dalam } \\
\text { ruang yang sama. Hal } \\
\text { ini menunjukkan bahwa } \\
\text { kedua objek ini memiliki } \\
\text { perbedaan suhu. Karpet } \\
\text { merupakan salah satu contoh } \\
\text { bahan penghambat panas } \\
\text { (thermal insulator) yang } \\
\text { cenderung mencegah suatu } \\
\text { objek menjadi lebih panas } \\
\text { atau lebih dingin. Disisi lain, } \\
\text { secangkir kopi yang berada } \\
\text { pada suhu kamar mengalami } \\
\text { penurunan .......dst. }\end{array}$ & $\begin{array}{l}\text { A. Energi dan Entalpi Zat } \\
\text { Berdasarkan peristiwa } \\
\text { tersebut di atas, manakah } \\
\text { yang jika kita pegang atau } \\
\text { berada disekitarnya akan } \\
\text { terasa panas? Mana pula } \\
\text { yang terasa dingin? Mengapa } \\
\text { ada reaksi yang terasa panas } \\
\text { dan ada yang terasa dingin? } \\
\text { Peristiwa pembuatan tempe } \\
\text { oleh mikroorganisme dan } \\
\text { pembakaran kayu merupakan } \\
\text { contoh reaksi eksoterm. } \\
\text { Sedangkan peristiwa } \\
\text { pembekuan es merupakan } \\
\text { reaksi endoterm. Apakah } \\
\text { yang dimaksud dengan reaksi } \\
\text { eks oterm endoterm? Mari } \\
\text { kita ......dst. }\end{array}$ & $\begin{array}{l}\text { Secara tradisional, } \\
\text { penduduk Indonesia } \\
\text { menggunakan tungku dari } \\
\text { kayu untuk memasak. } \\
\text { Pada perkembangannya, } \\
\text { digunakan minyak tanah } \\
\text { sebagai bahan bakar untuk } \\
\text { memasak (menggunakan } \\
\text { kompor minyak). } \\
\text { sekarang, kompor minyak } \\
\text { sudah jarang digunakan } \\
\text { karena pemerintah telah } \\
\text { melakukan program } \\
\text { konversi minyak tanah } \\
\text { menjadi LPG (elpiji).....dst } \\
\text { Energi bukan suatu materi, } \\
\text { tetapi sesuatu yang dapat } \\
\text { dimiliki oleh materi yang } \\
\text {........dst }\end{array}$ \\
\hline
\end{tabular}


Dilanjukan pada penghalusan teks dasar yang baik, dan hasilnya pada Tabel 3 .

(sumber), dilakukan sesuia kaidah penulisan

Tabel 3. Penggabungan dan Penghalusan

\section{Hasil Penggabungan Teks}

\section{Hasil Penghalusan Teks}

(Teks Dasar)
Secara tradisional, penduduk Indonesia menggunakan tungku dari kayu untuk memasak. Pada perkembangannya, digunakan minyak tanah sebagai bahan bakar untuk memasak (menggunakan kompor minyak). Sekarang, kompor minyak sudah jarang digunakan karena pemerintah telah melakukan program konversi minyak tanah menjadi LPG (elpiji). Hal ini karena LPG lebih efisien dan lebih murah. Benarkah pemakaian elpiji lebih murah dan lebih efisien dari pada minyak tanah? Jawaban terhadap permasalahan tersebut dapat dipahami apabila telah memahami konsep tentang termokimia.

Termokimia adalah bagian dari ilmu kimia yang mempelajari hubungan antara kalor( energi panas) dengan reaksi kimia atau proses-proses yang berhubungan dengan reaksi kimia. Dalam praktiknya, termokimia lebih banyak ......dst.

A. Pengantar Mengenai Perpindahan Energi dan Panas Reaksi

Pada malam hari, lantai terasa lebih dingin dari pada karpet yang ada dalam ruang yang sama. Hal ini menunjukkan bahwa kedua objek ini memiliki perbedaan suhu. Karpet merupakan salah satu contoh bahan ...dst.
Pendahuluan termokimia

Secara tradisional, penduduk Indonesia menggunakan tungku dari kayu untuk memasak Selanjutnya perkembangannya, digunakan minyak tanah sebagai bahan bakar untuk memasak. Saat ini kompor minyak sudah jarang digunakan karena pemerintah telah melakukan program konversi minyak tanah menjadi LPG (elpiji). Hal ini karena LPG lebih efisien dan lebih murah. Benarkah pemakaian elpiji lebih murah dan lebih efisien dari pada minyak tanah? Jawaban terhadap permasalahan tersebut dapat dipahami apabila telah memahami konsep tentang termokimia..... dst

Energi bukan suatu materi, tetapi sesuatu yang dapat dimiliki oleh materi yang memungkinkan objek berpindah. Setiap perubahan kimia dan perubahan fisik disertai dengan perubahan energi....dst

A. Pengantar Mengenai Perpindahan Energi dan Panas Reaksi

Pada malam hari, lantai terasa lebih dingin dari pada karpet yang ada dalam ruang yang sama. Hal ini menunjukkan .....dst.
Hasil penghalusan teks/konten kimia digabungkan (komposit) dengan indikator
EDL menghasilkan konten berbasis EDL seperti pada Tabel 4 .

Tabel 4. Penggabungan Konten- Indikatator (EDL)

\begin{tabular}{|c|c|c|}
\hline Penghalusan Teks & Indikator -Indikator EDL & $\begin{array}{l}\text { Penggabungan Teks Halus } \\
\text { dan Indikator EDL }\end{array}$ \\
\hline $\begin{array}{l}\text { Pendahuluan termokimia } \\
\text { Secara tradisional, penduduk } \\
\text { Indonesia menggunakan tungku } \\
\text { dari kayu untuk memasak. } \\
\text { Selanjutnya perkembangannya, } \\
\text { digunakan minyak tanah sebagai } \\
\text { bahan bakar untuk memasak. } \\
\text { Saat ini kompor minyak sudah } \\
\text { jarang digunakan karena } \\
\text { pemerintah telah melakukan } \\
\text { program konversi minyak tanah } \\
\text { menjadi LPG (elpiji). Hal ini } \\
\text { karena LPG lebih efisien dan lebih } \\
\text { murah. Benarkah pemakaian } \\
\text { elpiji lebih murah dan lebih } \\
\text { efisien dari pada minyak tanah? } \\
\text { Jawaban terhadap permasalahan } \\
\text { tersebut dapat dipahami apabila } \\
\text { telah memahami konsep tentang } \\
\text { termokimia.....dst. }\end{array}$ & $\begin{array}{l}\text { Indikator Discovery Learning menurut } \\
\text { Bruner Tahun } 1998 \text {. } \\
\text { 1. Menanggapi situasi dengan } \\
\text { berbagai cara } \\
\text { 2. Menginternalisasi cara yang sesuai } \\
\text { dengan lingkungan } \\
\text { 3. Peningkatan } \\
\text { berinteraksi } \\
\text { 4. Interaksi sistematis dengan guru } \\
\text { 5. Interaksi yang dibangun harus } \\
\text { berbasis lingkungan } \\
\text { 6. Meningkatkan kapasitas untuk } \\
\text { menangani (menyelsesikan/solusi) } \\
\text { berbagai berbagai masalah. } \\
\text { Ad. 1. Menanggapi situasi dengan } \\
\text { berbagai cara: } \\
\text { Menyelidiki masalah.....dst }\end{array}$ & $\begin{array}{l}\text { TERMOKIMIA } \\
\text { Pendahuluan Termokimia } \\
\text { saat kita mengolah makanan } \\
\text { menjadi makanan yang siap } \\
\text { dikonsumsi, kita membutuhkan } \\
\text { panas. Panas ini diperoleh } \\
\text { dari pembakaran bahan bakar, } \\
\text { misalnya minyak tanah atau } \\
\text { LPG. } \\
\text { Termokimia juga } \\
\text { merupakan ilmu kimia yang } \\
\text { khusus mempelajari energi } \\
\text { yang diserap atau dilepaskan } \\
\text { melalui reaksi-reaksi kimia } \\
\text { atau studi tentang perpindahan } \\
\text { dan perubahan energi. } \\
\text { Termokimia pada prakteknya } \\
\text { berhubungan dengan } \\
\text { pengukuran kalor...dst. }\end{array}$ \\
\hline
\end{tabular}

Gabungan konten dan indikator EDL dihaluskan seperti pada Tabel 5. 
Tabel 5. Komposit dan Penghalusan.

\begin{tabular}{|c|c|}
\hline Gabungan Teks Halus dan Indikator & Penghalusan Teks dan Indikator \\
\hline $\begin{array}{l}\text { TERMOKIMIA } \\
\text { Pendahuluan Termokimia } \\
\text { Saat kita mengolah makanan menjadi } \\
\text { makanan yang siap dikonsumsi, kita membutuhkan } \\
\text { panas. Panas ini diperoleh dari pembakaran bahan } \\
\text { bakar, misalnya minyak tanah atau LPG. } \\
\text { Termokimia juga merupakan ilmu kimia } \\
\text { yang khusus mempelajari energi yang diserap } \\
\text { atau dilepaskan melalui reaksi-reaksi kimia atau } \\
\text { studi tentang perpindahan dan perubahan energi. } \\
\text { Termokimia pada prakteknya berhubungan } \\
\text { dengan pengukuran kalor yang menyertai reaksi } \\
\text { kimia. Mempelajari perubahan kalor dari suatu } \\
\text { proses, perlu dikaji beberapa hal yang berhubungan } \\
\text { dengan energi seperti apa saja yang dimiliki suatu } \\
\text { zat, bagaimana energi tersebut berubah, bagaimana } \\
\text { mengukur perubahan energi, serta bagaimana pula } \\
\text { hubungannya dengan struktur zat....dst } \\
\text { Contoh soal } 1 \\
\text { Sebuah kelompok peternak sapi, mengumpulkan } \\
\text { kotoran sapi untuk dijadikan bahan bakar. Kotoran } \\
\text { sapi diproses menjadi bahan bakar yang menjadi } \\
\text { salah satu alternatif pembuatan bahan bakar } \\
\text { biogas...dst }\end{array}$ & $\begin{array}{l}\text { TERMOKIMIA } \\
\text { Pendahuluan Termokimia } \\
\text { Pada saat kita mengolah makanan, maka kita } \\
\text { membutuhkan panas. Panas ini diperoleh dari hasil } \\
\text { pembakaran bahan bakar seperti minyak tanah atau } \\
\text { gas LPG. Akibat panas dari bahan bakar, maka } \\
\text { beras berubah menjadi nasi dan sebagainya. } \\
\text { Termokimia adalah bagian dari ilmu kimia yang } \\
\text { mempelajari hubungan antara kalor (energi panas) } \\
\text { dengan reaksi kimia atau proses-proses yang } \\
\text { berhubungan dengan reaksi kimia. Termokimiajuga } \\
\text { merupakan ilmu kimia yang khusus mempelajari } \\
\text { energi yang diserap atau dilepaskan melalui reaksi- } \\
\text { reaksi kimia atau studi tentang perpindahan dan } \\
\text { perubahan energi. Termokimia pada prakteknya } \\
\text { berhubungan dengan pengukuran kalor atau energi } \\
\text { yang menyertai reaksi kimia. } \\
\text { A. Energi dan Perubahan Energi } \\
\text { Energi bukan suatu materi, tetapi sesuatu yang dapat } \\
\text { dimiliki oleh materi yang memungkinkan suatu } \\
\text { objek berpindah, berubah, atau ...dst. }\end{array}$ \\
\hline
\end{tabular}

Selanjutnya hasil penghalusan dibentuk menjadi sebuah prototipe modul setelah divalidasi dan uji skala terbatas, Gambar 2.

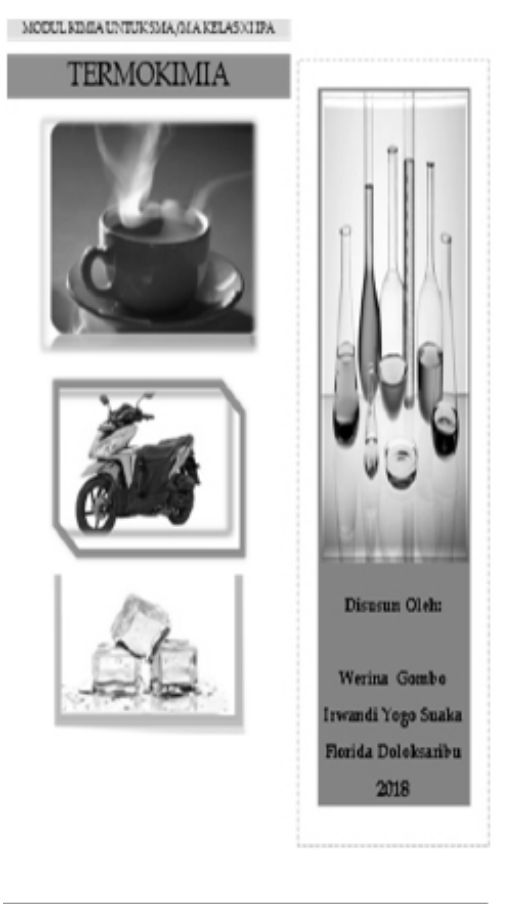

\section{TERMOKIMIA}

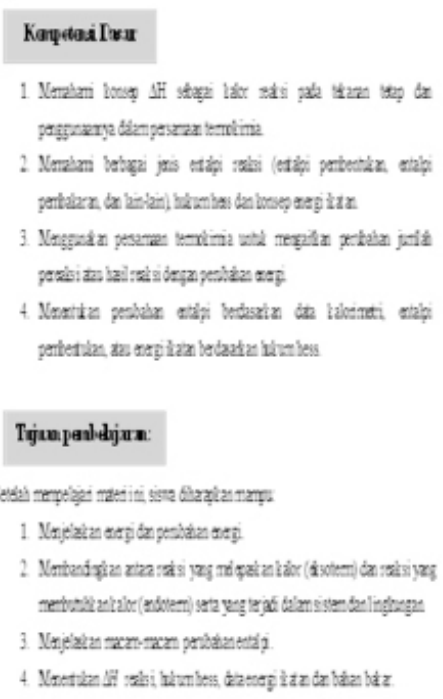

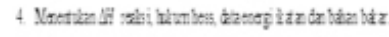
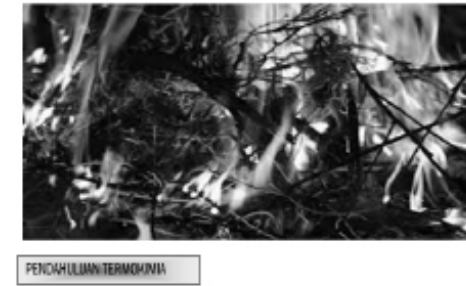

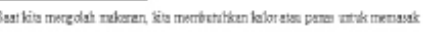

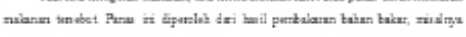
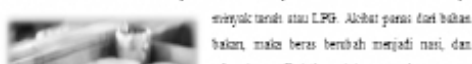

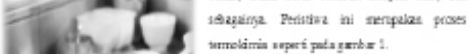

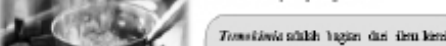
Pre, manpician twing

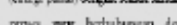
prosa mag bahthingan denge rak min

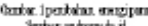

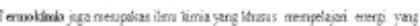

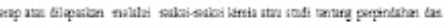

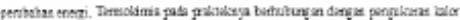

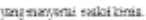

.. dst.

Gambar 2. MER Prototipe Modul Termokimia Berbasis EDL

Hasil validasi (expertjudgement) berdasarkan konten materi, konten media, dan konten bahasa seperti pada grafik Gambar 3. 


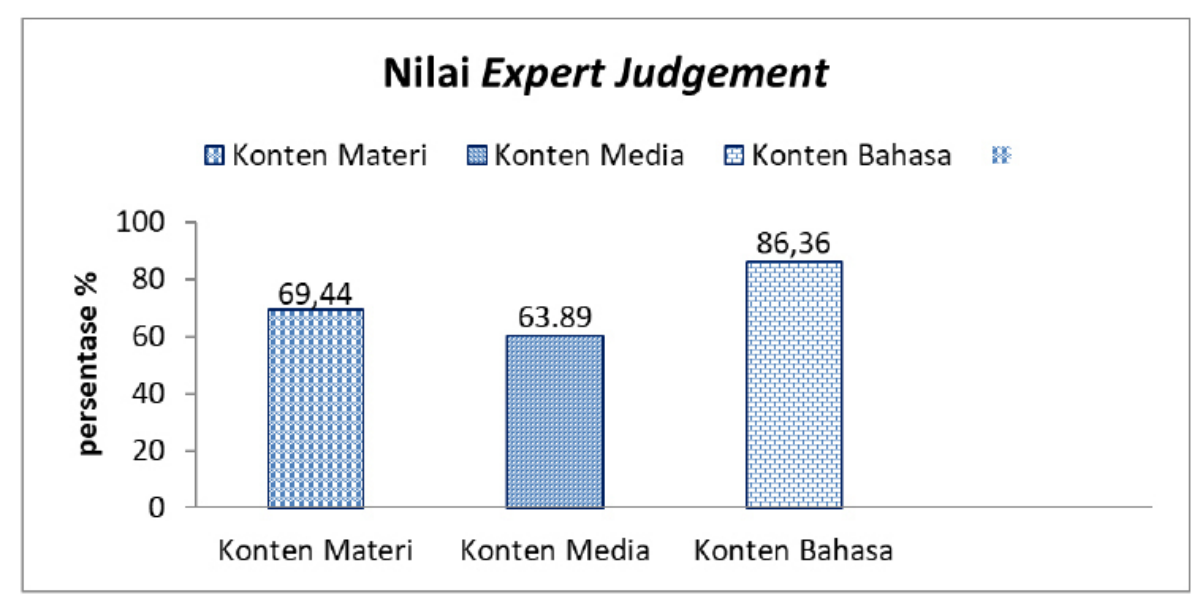

Gambar 3. Grafik Nilai Expert Judgement

Hasil pretes dan postes siswa Persentase N-gain peserta didik dapat dilihat menunjukkan peningkatan dengan nilai pada Gambar 4. $\mathrm{N}$-gain rata-rata 0,5 (kategori sedang).

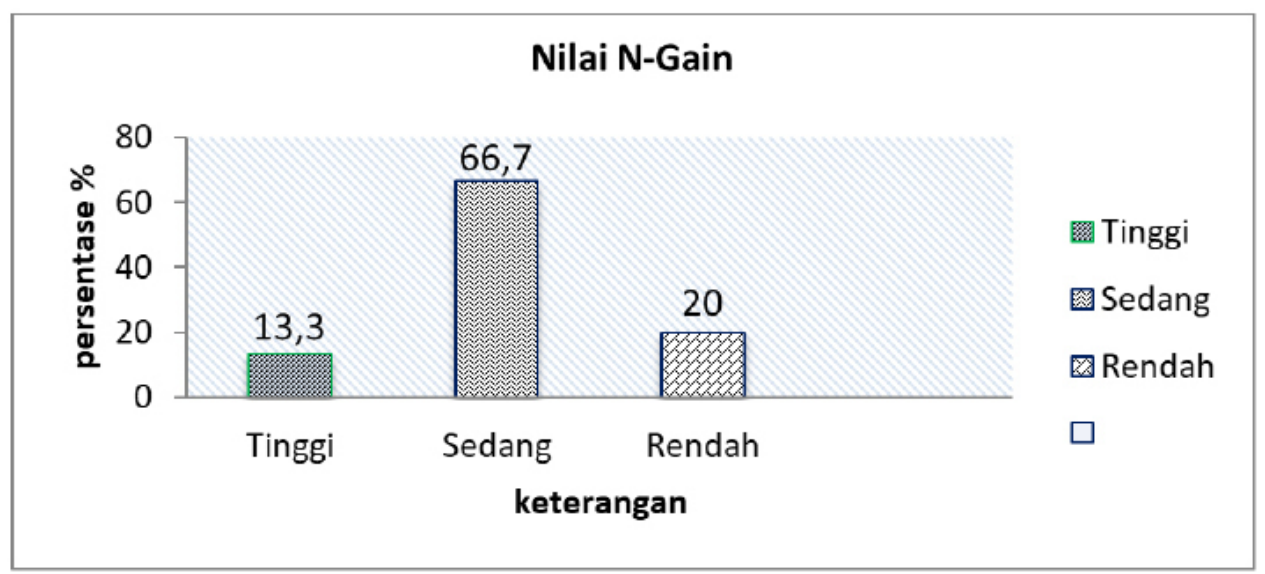

Gambar 4. Nilai n-Gain Peserta Didik

Hasil tanggapan guru terhadap modul ditunjukkan pada Tabel 6 dan Gambar 5.

Tabel 6. Tanggapan Guru terhadap modul

\begin{tabular}{|c|c|c|c|c|c|c|c|c|c|}
\hline \multicolumn{10}{|c|}{ Tanggapan Guru Terhadap Modul Kimia } \\
\hline \multirow{2}{*}{ No Item } & \multicolumn{2}{|r|}{ SB } & \multicolumn{2}{|r|}{ B } & \multicolumn{2}{|r|}{ TB } & \multicolumn{2}{|c|}{ STB } & \multirow{2}{*}{$\begin{array}{c}\text { Jumlah } \\
\text { Guru }\end{array}$} \\
\hline & $\mathbf{F}$ & $(\%)$ & $\mathbf{F}$ & $(\%)$ & $\mathbf{F}$ & $(\%)$ & $\mathbf{F}$ & $(\%)$ & \\
\hline 1 & 2 & $66.67 \%$ & 1 & $33.3 \%$ & 0 & $0.00 \%$ & 0 & $0.00 \%$ & 3 \\
\hline 2 & 2 & $66.67 \%$ & 1 & $33.3 \%$ & 0 & $0.00 \%$ & 0 & $0.00 \%$ & 3 \\
\hline 3 & 1 & $33.3 \%$ & 2 & $66.67 \%$ & 0 & $0.00 \%$ & 0 & $0.00 \%$ & 3 \\
\hline 4 & 2 & $66.67 \%$ & 1 & $33.3 \%$ & 0 & $0.00 \%$ & 0 & $0.00 \%$ & 3 \\
\hline 5 & 2 & $66.67 \%$ & 1 & $33.3 \%$ & 0 & $0.00 \%$ & 0 & $0.00 \%$ & 3 \\
\hline 6 & 2 & $66.67 \%$ & 1 & $33.3 \%$ & 0 & $0.00 \%$ & 0 & $0.00 \%$ & 3 \\
\hline 7 & 2 & $66.67 \%$ & 1 & $33.3 \%$ & 0 & $0.00 \%$ & 0 & $0.00 \%$ & 3 \\
\hline 8 & 2 & $66.67 \%$ & 1 & $33.3 \%$ & 0 & $0.00 \%$ & 0 & $0.00 \%$ & 3 \\
\hline Jumlah F & 13 & & 9 & & 0 & & 0 & & \\
\hline Rata-rata \% & & $62,4 \%$ & & $37,6 \%$ & & $0.00 \%$ & & $0.00 \%$ & \\
\hline Total F & & & & & 22 & & & & \\
\hline Total \% & & & & & 00.0 & & & & \\
\hline
\end{tabular}


Keterangan :

SB : Sangat Baik. Skor 3

B : Baik. Skor 2

TB : Tidak Baik. Skor 1

STB : Sangat Tidak Baik. Skor 0

F : Frekuensi.

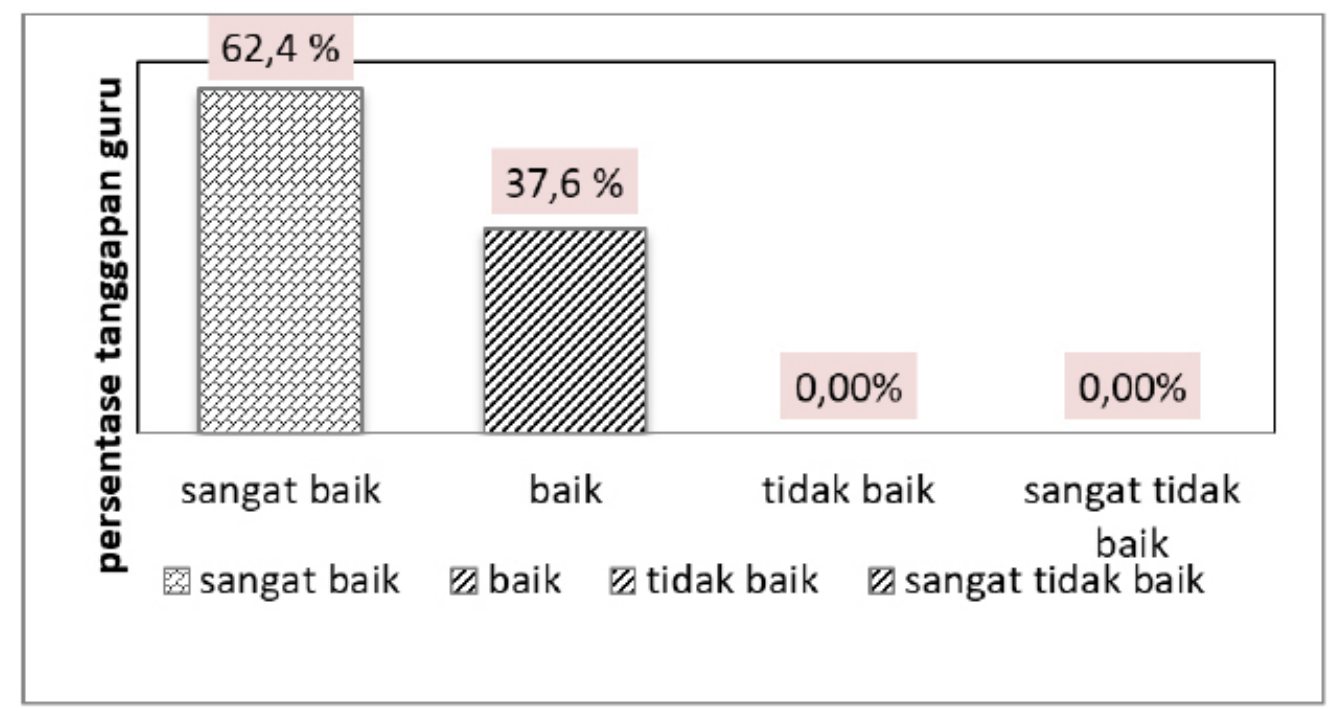

Gambar 5. Grafik tanggapan guru terhadap modul

Tanggapan guru secara keseluruhan dapat dilihat pada Tabel 7 dan Gambar 6.

Tabel 7. Persentase Tanggapan Peserta Didik

\begin{tabular}{|c|c|c|c|c|c|c|c|c|c|}
\hline \multicolumn{10}{|c|}{ Tanggapan Siswa Terhadap Modul Kimia } \\
\hline \multirow{2}{*}{ No Item } & \multicolumn{2}{|r|}{ SS } & \multicolumn{2}{|r|}{$\mathbf{S}$} & \multicolumn{2}{|c|}{ TS } & \multicolumn{2}{|c|}{ STS } & \multirow{2}{*}{$\begin{array}{c}\text { Jumlah } \\
\text { Siswa }\end{array}$} \\
\hline & $\mathbf{F}$ & $(\%)$ & $\mathbf{F}$ & $(\%)$ & $\mathbf{F}$ & $(\%)$ & $\mathbf{F}$ & $(\%)$ & \\
\hline 1 & 8 & $53.3 \%$ & 6 & $40 \%$ & 0 & $0.00 \%$ & 0 & $0.00 \%$ & 15 \\
\hline 2 & 11 & $73.3 \%$ & 4 & $26.67 \%$ & 0 & $0.00 \%$ & 0 & $0.00 \%$ & 15 \\
\hline 3 & 7 & $46.67 \%$ & 8 & $53.3 \%$ & 0 & $0.00 \%$ & 0 & $0.00 \%$ & 15 \\
\hline 4 & 7 & $46.67 \%$ & 7 & $46.67 \%$ & 0 & $0.00 \%$ & 0 & $0.00 \%$ & 15 \\
\hline 5 & 7 & $46.67 \%$ & 6 & $40 \%$ & 1 & $6.67 \%$ & 0 & $0.00 \%$ & 15 \\
\hline 6 & 4 & $26.67 \%$ & 8 & $53.3 \%$ & 0 & $0.00 \%$ & 0 & $0.00 \%$ & 15 \\
\hline 7 & 8 & $53.3 \%$ & 7 & $46.67 \%$ & 0 & $0.00 \%$ & 0 & $0.00 \%$ & 15 \\
\hline 8 & 4 & $26.67 \%$ & 11 & $73.3 \%$ & 0 & $0.00 \%$ & 0 & $0.00 \%$ & 15 \\
\hline 9 & 2 & $13.3 \%$ & 11 & $73.3 \%$ & 0 & $0.00 \%$ & 0 & $0.00 \%$ & 15 \\
\hline 10 & 0 & $0.00 \%$ & 11 & $73.3 \%$ & 4 & $26.67 \%$ & 0 & $0.00 \%$ & 15 \\
\hline 11 & 4 & $26.67 \%$ & 9 & $60 \%$ & 1 & $6.67 \%$ & 0 & $0.00 \%$ & 15 \\
\hline 12 & 3 & $20 \%$ & 12 & $80 \%$ & 0 & $0.00 \%$ & 0 & $0.00 \%$ & 15 \\
\hline 13 & 9 & $60 \%$ & 6 & $40 \%$ & 0 & $0.00 \%$ & 0 & $0.00 \%$ & 15 \\
\hline 14 & 5 & $33.3 \%$ & 8 & $53.3 \%$ & 2 & $13.3 \%$ & 0 & $0.00 \%$ & 15 \\
\hline 15 & 4 & $26.67 \%$ & 11 & $73.3 \%$ & 1 & $6.67 \%$ & 0 & $0.00 \%$ & 15 \\
\hline 16 & 1 & $6.67 \%$ & 11 & $73.3 \%$ & 1 & $6.67 \%$ & 0 & $0.00 \%$ & 15 \\
\hline Jumlah F & 84 & & 136 & & 9 & & 0 & & \\
\hline Rata-rata $\%$ & & $34,90 \%$ & & $56,61 \%$ & & $8,39 \%$ & & $0.00 \%$ & \\
\hline Total F & & & & & & & & & \\
\hline Total \% & & & & & 100 & & & & \\
\hline
\end{tabular}


Keterangan :

SS : Sangat Setuju (sangat positif). Skor (3)

S : Baik. Skor (positif). Skor (2)

TS : Tidak Baik (tidak positif). Skor (1)

STS : Sangat Tidak Baik (sangat tidak positif). Skor (0)

F : Frekuensi.

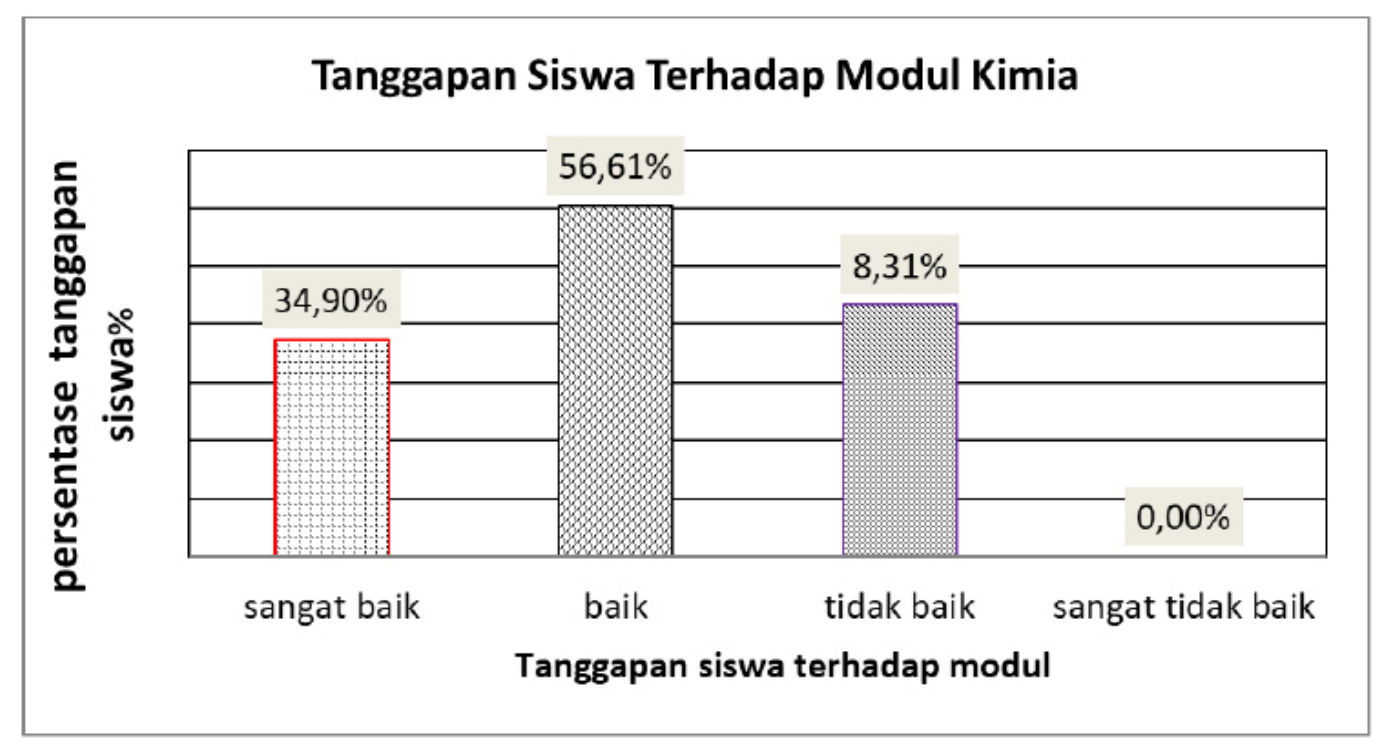

Gambar 6. Garfik tanggapan siswa terhadap modul

\subsection{Pembahasan}

Rekonstruksi bahan ajar kimia pada materi termokimia berbasis environment discovery learning dilakukan untuk perbaikan dan inovasi pada modul disebabkan masih banyak modul belum mendukung perkembangan literasi sains siswa. Rekonstruksi modul ini bertujuan untuk menyusun kembali materi kimia dari berbagai sumber-sumber untuk dijadikan sebuah bahan ajar dalam bentuk modul berbasis kebutuhan siswa. Modul lebih diarahkan untuk mengakomodasi keterkaitan konten dan konteks berbasis kebutuhan siswa. Sejalan dengan tujuan rekonstruksi model pendidikan (Duit,2010) dan penelitian yang dilakukan oleh Rostikawati dan Permanasari (2016) bahwa rekonstruksi yang dilakukan harus mempertimbangkan tujuan pendidikan dan aspek kognitif serta afektif siswa, sehingga materi pembelajaran dapat lebih mudah dipahami oleh siswa.

Sebelum uji coba skala terbatas dilakukan, modul kimia berbasis environment discovery learning yang direkonstruksi telah divalidasi oleh tim ahli untuk mengetahui kelayakan konten materi, kelayakan media, dan tata bahasa atau keterbacaan seperti yang ditunjukkan pada Gambar 1. Validasi kelayakan bahan ajar menjadi dasar ujicoba skala terbatas dan selanjutnya untuk ujicoba skala luas. Hasil validasi modul pada konten materi sebesar 69.44\% (layak digunakan) dengan perbaikan pada modul adalah kedalaman materi kimia termokimia perlu digali lebih mendalam, bahasa yang disajikan harus lebih ilmiah, dan gambar-gambar dan ilustrasi atau analogi harus lebih disesuaikan. Validasi kelayakan modul pada konten media sebesar 63,89\% (layak digunakan), perbaikan pada modul adalah sistem penulisan, setiap latihan soal dan tugas mandiri, dan urutan dalam penyusunan modul perlu diperhatikan kembali. Validasi kelayakan modul pada konten bahasa sebesar $86.36 \%$ (sangat layak digunakan), perbaikan untuk modul adalah kemampuan memotivasi siswa perlu dikembangkan.

Nilai N-Gain siswa memiliki kategori tinggi sebanyak $13.33 \%$, kategori sedang sebanyak $66.67 \%$, dan kategori rendah sebanyak $20.00 \%$ seperti yang ditunjukkan pada gambar 2. Keadaan ini menunjukkan terjadi peningkatan dalam pemahaman 
konsep. Namun beberapa kendala yang dihadapi siswa dalam pembelajaran adalah waktu penelitian yang kurang efektif sehingga siswa merasa jenuh, sehingga diungkinkan tingkat perolehan $\mathrm{N}$-gainnya tidak maksimal, hal ini dapat juga dilihat dari tanggapan siswa ditunjukkan pada tabel 8 dan gambar 4, diana asih ada $8,31 \%$ siswa yang belum merasa puas dengan modul tersebut. Namun berbeda dengan tanggapan tanggapan guru terhadap modul. Hasil analisis persentase tanggapan guru menunjukkan sangat positif sebesar $16.73 \%$ dan positif dan $9.93 \%$ seperti ditunjukkan tabel 7 dan gambar 3, artinya bahwa rekonstruksi modul kimia sangat efektif untuk digunakan dalam implementasi pembelajaran kimia.

\section{KESIMPULAN}

Berdasarkan hasil penelitian yang telah dilakukan, maka dapat disimpulkan bahwa rekonstruksi modul kimia berbasis environment discovery learning, menggunakan model of educattional reconstruction (MER) melalui 3 tahapan dasar yaitu: analisis struktur konten, penelitian pembelajaran, dan implementasi dan evaluasi pembelajaran. Selanjutnya kelayakan rekonstruksi modul kimia, dapat dilihat dari nilai valiasi konten materi, konten media, dan konten bahasa dan dianalisis melalui nilai expert judgement. Hasil analisis konten materi dengan persentase sebesar $69.49 \%$, konten media sebesar $63.89 \%$ dan konten bahasa dengan persentase sebesar $86.36 \%$, dari nilai validasi ini menyatakan modu layak digunakan. Peningkatan pemahaman konsep dapat dilihat dari nilai N-Gain siswa. Hasil analisis nilai $\mathrm{N}-G a i n$ siswa sedang sebesar 0.5 , terjadi peningkatan pemahaman siswa dalam pembelajaran skala terbatas. Tanggapan guru terhadap modul kimia sangat positif dengan persentase sebesar $62.4 \%$ dan positif sebesar $37.6 \%$. Sedangkan tanggapan siswa terhadap modul kimia sangat positif dengan persentase sebesar $34.90 \%$ dan positif sebesar $56.61 \%$.

\section{DAFTAR PUSTAKA}

Arends, R. (2008). Learning to Teach. Yogyakarta: Pustaka Pelajar.

Ariyana, L. T. (2011). Analisis Butir Soal Ulangan Akhir Semester Gasal IPA Kelas IX SMP di Kabupaten Grobogan [Universitas Negeri Semarang]. In Jurnal Materi dan Pembelajaran Fisika (Vol. 10, Issue 1). https://jurnal.uns.ac.id/jmpf/article/view/42084

Budiningsih. (2005). Model Discovery Learning. Jakarta:Pustaka Mandiri.

Doloksaribu, F., Mudzakir, A., Sholihin, H., \& Sudargo, F. (2014). Model Education Reconstruction (MER) Bahan Ajar Penelitian Laboratorium (PL) Konteks Zeolit Berbasis Problem Solving-Decision Making (PSDM). Jurnal Penelitian PendidikanA \& A (Semarang), 31(2), 20-29. https://doi.org/10.15294/jpp.v31i2.5694

Duit, R. (2007). Science education research internationally: Conceptions, research methods, domains of research. Eurasia Journal of Mathematics, Science and Technology Education, 3(1), 3-15. https://doi.org/10.12973/ ejmste/75369

Duit, R., Gropengießer, H., Kattmann, U., Komorek, M., \& Parchmann, I. (2012). The Model of Educational Reconstruction - a Framework for Improving Teaching and Learning Science1. In Science Education Research and Practice in Europe (pp. 13-37). SensePublishers. https://doi.org/10.1007/978-94-6091900-8 2

Erlidawati, \& Habibati. (2020). Penerapan Model Discovery Learning Untuk Meningkatkan Aktivitas Dan Hasil Belajar Peserta Didik Pada Materi Termokimia. Jurnal Pendidikan Sains Indonesia (Indonesian Journal of Science Education), 8(1), 92-104. https://doi.org/10.24815/jpsi.v8i1.16099

Indriyanti, R., \& Prasetyo, Z. K. (2018). Improving the experiment report writing skills of fifth graders through the discovery learning method. Jurnal Prima Edukasia, 6(1), 113. https://doi.org/10.21831/jpe.v6i1.17284

Istikomah, I. (2013). Penerapan Model Discovery Learning Untuk Meningkatkan Kualitas Proses Dan Hasil Belajar Geografi Pada Materi Pemanfaatan Lingkungan Hidup Kaitannya Dengan Pembangunan Berkelanjutan Di Sma Batik 1 Surakarta Tahun Ajaran 2013/2014. Pendidikan Geografi, 2(2), 87-98. http://garuda. ristekbrin.go.id/documents/detail/1419835

Nur, F., Tayeb, T., Widayanti, V. M., Sriyanti, A., \& Nurhidayah, N. (2020). Effectiveness Of Discovery Learning Model On Students' Mathematical Problem Solving Ability. MaPan, 8(1), 134. https://doi.org/10.24252/ mapan.2020v8n1a10 
Prakasiwi, R., \& Ismanto, B. (2018). Efforts to Improve Scientific Thinking Skills Through Application Discovery Model-Based Learning Environment Around. Journal of Educational Science and Technology (EST), 1(1), 151. https://doi.org/10.26858/est.v1i1.6047

Pratiwi, F. A., Hairida, \& Rasmawan, R. (2014). Pengaruh Penggunaan Model Discovery Learning Dengan Pendekatan Saintifik Terhadap Keterampilan Berpikir Kritis Siswa SMA. Jurnal Pendidikan Dan Pembelajaran Khatulistiwa, 3(7), 1-18. http://jurnal.untan.ac.id/index.php/jpdpb/article/view/6488

Resty, Z. N., Muhardjito, M., \& Mufti, N. (2019). Discovery Learning Berbantuan Schoology: Upaya Peningkatan Kemampuan Berpikir Kritis. Jurnal Pendidikan: Teori, Penelitian, Dan Pengembangan, 4(2), 267-273. https://doi.org/10.17977/JPTPP.V4I2.12040

Rostikawati, D. A., \& Permanasari, A. (2016). Rekonstruksi bahan ajar dengan konteks socio-scientific issues pada materi zat aditif makanan untuk meningkatkan literasi sains siswa. Jurnal Inovasi Pendidikan IPA, 2(2), 162. https://doi.org/10.21831/jipi.v2i2.8814

Rubini, B., Pursitasari, I. D., Ardianto, D., \& Nugraha, H. (2017). Improving Students' Scientific Literacy On Environmental Pollution Through Laboratory-Based Learning. Jurnal Pengajaran MIPA, 22(2), 205210. https://doi.org/10.18269/JPMIPA.V22I2.8459

Yerimadesi, Y., Bayharti, B., Handayani, F., \& Legi, W. F. (2017). Pengembangan Modul Kesetimbangan Kimia Berbasis Pendekatan Saintifik Untuk Kelas XI SMA/MA. Sainstek : Jurnal Sains Dan Teknologi, 8(1), 97. https://doi.org/10.31958/js.v8i1.444

Yerimadesi, Y., Putra, A., \& Ririanti, R. (2017). Efektivitas Penggunaan Modul Larutan Penyangga Berbasis Discovery Learning Terhadap Hasil Belajar Siswa Kelas XI MIA SMAN 7 Padang. Jurnal Eksakta PendidikaN (JEP), 1(1), 23. https://doi.org/10.24036/jep/vol1-iss1/29 